\title{
INFLUENCE DU COMPARTIMENT TROPHIQUE DANS LES RÉPONSES DES POPULATIONS DE POISSONS AUX VARIATIONS ARTIFICIELLES DE DÉBIT.
}

\author{
D. J. ORTH
}

Department of Fisheries and Wildlife Sciences, Virginia Polytechnic Institute and State University,

Blacksburg, Virginia 24061-0321 (USA).

\section{RÉSUMÉ (traduit par les éditeurs)}

Les réponses des populations de poissons aux altérations de débit sont assez peu souvent correctement prédites à partir des simulations physiques d'habitat. Actuellement, les évaluations de débit résené sont basées sur des analyses de l'habitat physique, qui sont supposées avoir une influence sur ces populations. Cela conduit au dilemme en matière de détermination de ces débits : combien d'espèces et de stades faut-il analyser et comment pondérer leur importance respective ? Dans certains cours d'eau, les simulations d'habitat physique issues de PHABSIM (Physical Habitat Simulation) pour les poissons les plus courants montrent une surface pondérée utile insensible ou maximum à faible débit. Or, les débits moyens à forts débits sont indubitablement importants pour différentes raisons, telles que le recrutement des espèces inféodées à la plaine alluviale, le nettoyage du fond du lit, les entrées de matière organique et la production des invertébrés benthiques. La densité, la diversité et la production des insectes aquatiques dans différents types de cours d'eau montrent des variations spatiales et interannuelles considérables, souvent directement reliables aux débits. De même, la croissance et le succès de prise de nourriture des poissons varient en fonction de l'abondance des proies. Un modèle de chaîne trophique a été développé pour étudier l'influence de la nourriture de base (insectes aquatiques, proies constituées par les poissons de petite taille et écrevisses) sur la production des poissons prédateurs clé (Black bass à petite bouche, Micropterus dolomieu, Rock bass, Ambloplites rupestris, et Poisson chat à tête plate, Pylodictis olivaris) dans un grand cours d'eau à régime thermique chaud. L'analyse du modèle indique que la production des poissons est très dépendante de la disponibilité des proies, en particulier les insectes aquatiques et les écrevisses. A partir des analyses du modèle et de la revue des études sur la production des insectes et les succès de capture des proies par les poissons, je fais l'hypothèse que les réductions de débit pendant la saison de croissance sont de nature à diminuer la production d'insectes et, par là même, d'altérer indirectement la production de poissons pêchables. Les estimations de débit à réserver et les recherches associées devraient s'intéresser (1) à un plus large éventail d'espèces, en particulier les plus sensibles, (2) à des analyses de l'habitat à une échelle médiane plus appropriée, (3) aux effets indirects des débits sur la structure trophique, (4) à des tests et des améliorations des critères de préférence d'habitat, et (5) à la mise en oeuvre de modèles individus centrés pour évaluer différents régimes des débits.

\section{FOOD WEB INFLUENCES ON FISH POPULATION RESPONSES TO INSTREAM FLOW.}

\section{SUMMARY}

Fish population responses to changes in streamflow have seldom been correctly forecasted from physical habitat predictions. Yet, practical instream flow assessments rely on analyses of physical habitat dynamics, which are presumed to influence fish populations. This leads to the instream flow dilemma: how many species and life stages to analyze and how to weight the importance of each. In some streams, PHABSIM (Physical 
Habitat Simulation) analyses for common warmwater fishes indicate that weighted usable area is either insensitive or maximized at low flows. However, average to high flows are undoubtedly important for a variety of reasons, such as recruitment of floodplain tree species, streambed scouring, organic matter inputs, and benthic invertebrate production. Density, diversity, and production of aquatic insects in a variety of streams show considerable annual and spatial variation, often directly attributable to streamflow. Similarly, growth and foraging success of fishes varies due to prey abundance. A food web model was developed to investigate the influence of the food base (aquatic insects, small prey fishes, and crayfish) on production of key predatory fishes (smallmouth bass Micropterus dolomieu, rock bass Ambloplites rupestris, and flathead catfish Pylodictis olivaris) in a large warmwater stream. Analysis of the model suggested that the production and yield of the fishes were strongly dependent on the bottom-up influence of prey, primarily aquatic insects and crayfish. From model analyses and review of studies on insect production and foraging success of fish, I hypothesize that decreases in flow during the growing season may decrease insect production and, thereby, indirectly depress sport fish production. Practical instream flow assessments and research should address (1) broader array of taxa, especially suspected sensitive species, (2) appropriateness of meso-scale habitat analyses, (3) indirect effects of flow on the trophic structure, (4) rigorous testing and refinement of habitat suitability criteria, and (5) efficacy of individual-based models for evaluating alternative flow regimes.

\section{INTRODUCTION}

In every instream flow assessment, the fundamental question is the effect of alternative flows on resource quality -- on this point there is no debate. There is more debate over what resources are considered and how to measure resource quality. The quality of the habitat for fishes is frequently measured by weighted usable area (WUA) indices with the Instream Flow Incremental Methodology (IFIM). The reliance on weighted usable area for "favored" fish species for trade-off analyses, such as described by FARGO (1991) for hydropower license review, raises serious doubt over our effectiveness in protecting the environment. In every instream flow assessment we implicitly ask ourselves : "What is the most important limiting factor and will it be influenced by a change in streamflow ?" It may be suitable living space (a local variable), as described by the physical characteristics of depth, velocity, substrate, or cover. But what if it is food or other regional variables ? Factors other than flow regime (water quality, energy, biotic interactions) can explain substantial variation in aquatic biota.

Twenty-nine years ago, CHAPMAN (1966) suggested that both food and space determined densities of stream salmonids in summer and that space was more critical in winter. Numerous studies done since that time have supported these early notions of territorial size requirements and, to some extent, its dependence on food (GRANT and KRAMER, 1990 ; TITUS, 1990). One could argue that the microhabitat requirements for fish also describe habitat for their food base, yet this is only true for fishes that feed in the same place that their prey live and grow. Many of our favored game fishes select microhabitats that are close to, but very different from, the microhabitats where their prey are produced (JOWETT, 1992 ; AADLAND, 1993). Furthermore, migratory riverine fishes depend on large-scale variables that determine suitability of local environments, such as barriers, distance to sea, and river gradient (McDOWALL, 1993).

In this paper I place the stream fish in the context of their food web and review studies that address two questions. First, is there evidence that the invertebrate prey base for fishes responds to instream flow ? Second, is there evidence that food limits the growth, productivity, or survival of stream fishes ? After reviewing recent literature, 1 then make suggestions for practical instream flow assessments and future research directions.

\section{THE DILEMMA OF INSTREAM FLOW ASSESSMENT}

At the early stages of instream flow assessments, we all struggle with the question "Which fish species should we focus on ?" and normally select one or a few favored game fish. The arguments in support for this focus on the fish are often repeated : (1) habitat 
requirements are well known ; (2) fish are closely related to management objectives ; and (3) it would be costly to study too many species. However, the expected cost savings can be offset by the cost of bad decisions (CAIRNS, 1986). In the arena of instream flow, these costs may be unnecessary power losses or limits on water withdrawal, or fishery or other ecosystem losses. IFIM and PHABSIM (Physical Habitat Simulation System), as currently used (NESTLER et al., 1989), are intended to provide advice to managers on the consequences of alternative flow regimes. However, in diverse communities the outcome may be highly sensitive to the species and life stages selected for study (LEONARD and ORTH, 1988). A broadening of environmental ethics is needed to protect riverine species and ecosystems before they become endangered (HUGHES and NOSS, 1992).

In my dissertation research, admittedly of short duration, I identified 130 unique taxa of benthic invertebrates and 28 species of fish in Glover Creek, Oklahoma (ORTH et al., 1982 ; ORTH and MAUGHAN, 1984), which is typical of species richness for temperate streams. This diversity of invertebrates leads to a stability of the food base for fishes and the maintenance of some well-known and some less-well-known ecosystem processes. Beyond their food value there are other values in preserving habitat for these animals, values that are not dependent on use by humans. I am not suggesting that in routine instream flow assessments that we should study 158 species intensely. However, we must recognize the diversity of ecological requirements and the key biological interactions when selecting study questions for these assessments.

If we focus on only one component of the life requisites of a species (i.e., habitat or food), then we assume that the other will never be in short supply. Is there evidence to support this assumption ? I am certain there are numerous examples where PHABSIM analyses of favored fish species has resulted in optimum flows that appear to be unrealistically low. There are examples where weighted usable area alone was a poor predictor of fish population density (LOAR et al., 1985 ; IRVINE et al., 1987 ; SCOTT and SHIRVELL, 1987 ; WILEY et al., 1987) and others where weighted usable area at a critical stage was a good predictor of year-class strength (BOVEE, 1988 ; NEHRING and ANDERSON, 1993 ; BOVEE et al., 1994). There are also numerous examples to demonstrate importance of streamflow on recruitment of riparian vegetation (STROMBERG and PATTEN, 1991 ; NILSSON et al., 1991) and eventually large woody debris, invertebrate assemblages, and channel structure (PETTS, 1984). The important conclusion drawn from these studies is that we must not uncritically accept the assumption that physical habitat on a local scale is the limiting factor for stream fish, nor unwittingly relay that notion to water managers. The instream flow dilemma is having to choose between (1) relying on a few well-studied fishes and being uncertain about the ecosystem functions that are implicitly ignored or (2) examining numerous fish, invertebrate, and plant habitat requirements and being uncertain about how to interpret and weight each component.

As an example of the potential dilemma, consider the New River in West Virginia, which supports thirty-two fish species, an array of insect, mollusc, and decapod fauna, and a notable sport and invertebrate bait (crayfish) fisheries (NIELSEN and ORTH, 1988 ; LOBB and ORTH, 1991 ; ROELL and ORTH, 1994). Hawks Nest Hydroelectric Project (Federal Energy Regulatory Commission No. 2512) diverts water (up to $283 \mathrm{~m}^{3} / \mathrm{sec}$ ) through a tunnel bypassing a $8.5-\mathrm{km}$ reach of river. A minimum release of $0.7 \mathrm{~m}^{3} / \mathrm{sec}$ in the bypass reach had not extirpated the entire fish fauna, yet the numbers and quality of the fishing were depressed. Analysis of weighted usable area versus discharge relations for several fishes indicated that living space was maximized for most fishes at flows well below the $65 \mathrm{~m} 3 / \mathrm{sec}$ (September median, aquatic base flow) recommended by the U.S. Fish and Wildlife Service. This analysis, and others like it, requires the assumption that fish are limited only by the amount of suitable living space and that food is not limiting the growth and survival of the fish and not expected to change with alternative flows. A further complication is that habitat availability for certain fish species in some channel types (sensu ROSGEN, 1994) does not change dramatically with stream flow (LEONARD and ORTH, 1988 ; PUSEY and ARTHINGTON, 1991). To make assessments based on habitat available to fish alone seems preposterous.

In the short-term, we will not have the predictive capability that we desire to aid in negotiating appropriate instream flow regimes. Therefore, we must rely on hydrologic descriptions of streamflow (cf. HILL et al., 1991) as a starting point for negotiations. 
However, as the U.S. population continues to grow by about 3 million people each year, the demands for water for power production and off-stream uses will become so acute that fisheries and aquatic scientists will have to make more realistic biological predictions of the consequences of off-stream water use. To assist in these assessments, I suggest that scientists make greater use of trophic models, individual-based models, and the mesoscale level of analysis.

\section{TROPHIC MODELS}

Two simple views of trophic structure have dominated recent ecological theory (POWER, 1990, 1992). The productivity (or "bottom-up") model predicts that as primary productivity of the ecosystem increases, the biomass of lower trophic levels increase and biomasses of all trophic levels are positively correlated. The top-down, or food-chain, model predicts that the top-down influence of top carnivores affects alternate trophic levels and positive correlations exist only between non-adjacent trophic levels. These views are embodied in the environmental stress model of MENGE and OLSON (1990), which predicts that the outcome depends on whether the prey or the consumers are more influenced by stress. If the consumer is stressed, the consumer declines but the prey increases. However, if the prey is stressed more, both prey and consumer trophic groups will decline with the stress. These notions have important implications for instream flow management. First, to predict the influence of flow changes, we must consider which trophic groups are most affected by a proposed flow change. Second, monitoring and assessment of the impacts of flow-related stress are misleading if they rely on a single trophic level. If we focus only on physical habitat in instream flow assessments, then we assume that trophic interactions (food limitation or predation) will not limit the "favored" fish populations.

\section{INVERTEBRATE RESPONSES TO FLOW}

Does the invertebrate assemblage respond to changes in stream flow? There are many examples where drastic flow regulation (i.e., hydro peaking) causes declines in density and diversity of the invertebrate fauna. I do not review these studies here. Rather, I concentrate most of my review on the question of minimum instream flows. The disturbance frequency due to storm flows in runoff streams increases the diversity and leads to invertebrate assemblages that are in a perpetual state of recovery (RESH et al., 1988 ; REICE et al., 1990). Natural experiments demonstrate effects of the extreme flows, either high or low on invertebrate assemblages. Species richness and diversity of invertebrates in a northern California (U.S.A.) stream declined in years of extreme drought or high rains in the wet season and densities of rheophilic invertebrates declined in drought years (McELRAVY et al., 1989). In another natural experiment, five-to-ten fold increases in maximum summer invertebrate densities were observed in wet years (SCHLOSSER and EBEL, 1989) ; increases in blackflies and net-spinning caddisflies were attributed to increased velocity and organic matter input. Characterization of the required hydraulic conditions has been done for several insects (OSBORNE and HERRICKS, 1987 ; GORE, 1989 ; WETMORE et al., 1990 ; JOWETT et al., 1991). Net-spinning caddisflies are more efficient at foraging under certain velocity conditions (GEORGIAN and THORP, 1992), which suggests one mechanism to partially explain observed variations.

In addition to creating more physical habitat, higher flow brings in more food (organic matter) for all invertebrate collectors. Chironomid growth in a low-gradient, coastal plain stream was strongly influenced by flow and associated organic matter inputs (HAUER and BENKE, 1991). The quality and quantity of food for invertebrates depend on flow and proximity to upstream sources (MORIN and PETERS, 1988 ; MEYER, 1990). Therefore, a landscape perspective for aquatic communities (SCHLOSSER, 1991) is an important consideration in instream flow assessments.

The invertebrate community is sensitive to changes in stream flow and, consequently, food webs change in response to flow (POWER, 1990 ; STRANGE et al., 1992 ; CLOSS and LAKE, 1994). However, there have been few attempts to make predictions of invertebrate community responses to flow changes before they occur. Artificial flow increases can dramatically increase insect densities. After 24 days, stream 
channels with doubled flow had over three times the density of insects, especially netspinning caddisflies (Hydropsyche) ; Chironomidae, blackflies, and mayflies also increased (SCHLOSSER and EBEL, 1989). On a much larger scale, an increase in minimum flow from 3 to $142 \mathrm{~m}^{3} / \mathrm{sec}$ below a large peaking hydroelectric dam resulted in 100-fold increase in summer invertebrate densities, mostly chironomids and the net-spinning caddisfly, Cheumatopsyche (WEISBERG et al., 1990). A less dramatic reduction in the frequency of high flows and low flows below hydroelectric dams can result in major increases in invertebrate densities (MORGAN et al., 1991).

\section{FISH - INVERTEBRATE RELATIONS}

In this section I explore the nature of the evidence that the invertebrate prey base limits growth, productivity, and survival of stream fishes. After minimum flows were established below Conowingo Dam (Susquehanna River), the dramatic increases in invertebrate densities resulted in higher stomach fullness measures and better fish growth and condition (WEISBERG and BURTON, 1993). In this case, it is not known whether the fish populations increased. In a long-term study unrelated to streamflow, WATERS (1982) observed a positive correlation between production, year-class strength, and production/biomass ratio of brook charr (Salvelinus fontinalis) and production of Gammarus, its principal prey. This suggests a strong bottom-up influence for this tightly coupled predator-prey system. In more species-rich stream communities, BOWLBY and ROFF (1986) observed strong habitat and top-down influences, but no bottom-up influences on trophic structure in temperate streams. The spatial distributions of biomass and numbers of invertebrates and fish were complementary ; invertebrates dominated riffles and fish dominated pools.

In experimental stream studies, fish are likely to respond to changes in productivity at the base of the food web (WARREN et al., 1964). In contrast natural populations of stream fish are highly variable (GROSSMAN et al., 1990) and the coefficient of variation (CV) in abundance is positively correlated with the CV of discharge (BAYLEY and LI, 1992). I must ask whether the disturbance effects suppress fish densities such that habitat and food levels during intervening periods are not major limitations on growth and survival. If suitable habitats are not saturated we shouldn't expect a density-dependent response that would limit population size (GRANT and KRAMER, 1990). Current theory of salmonid population regulation predicts that year-class size is set in the months after emergence, but the time taken to regulate numbers decreases with high initial population density (TITUS, 1990). Therefore, the habitat and food conditions during this early time period when numbers are regulated should be critical variables for population success.

Long-term empirical studies provide evidence that habitat in some key life stages can limit population abundance. Trout recruitment in Colorado streams was highly dependent on discharge and weighted usable area during early life stages (NEHRING and ANDERSON, 1993). Recruitment of smallmouth bass and rock bass was most highly correlated with measures of habitat available for the age-0 fish (BOVEE et al., 1994). However, empiricism cannot discriminate between the multiple causes (refuge from predation, food production and increased foraging efficiency) that are related to habitat measures. The relative importance of biotic and abiotic variables in influencing variability in stream fish populations shifts in space and time (JENNINGS and PHILIPP, 1994). Therefore, the effect of biotic variables is contingent on past stochastic factors.

A major dilemma in instream flow assessments is our immature capabilities for considering the indirect effects of flow on multiple trophic levels. Several independent studies on productivity of the New River, West Virginia, USA, were integrated into a model of energy flow through the community (ROELL and ORTH, 1994). Strong trophic links existed between three carnivorous fishes (smallmouth bass, rock bass, and flathead catfish) and crayfish, smaller fish, and aquatic insects (ROELL and ORTH, 1993). The habitats that support the insect productivity are areas with perceptible current. Crayfish production was seven times higher and hellgrammite (Corydalus cornutus) production was twenty times higher in shallow, fast-current habitats than in nearby pools, yet the fishes tended to be more generally distributed (LOBB and ORTH, 1991). At young life stages the 
mayflies (Ephemeroptera) are major energy sources for smallmouth bass (EASTON and ORTH, 1992). The energy flow model describes the community with 13 components (Table I) linked with non-linear feeding rate functions. Monte Carlo simulations, in which input parameters were randomly varied, were used to suggest which processes were most important in determining biomass of each component. Most of the variation in biomass at the end of simulations could be attributed to variation in parameters that described the consumption of prey by each component. The top-down influence was less important than bottom-up influences, but was nevertheless important for the very strong trophic links (crayfish-fish interactions). Based on this model, changes in insect or crayfish production, which are highly flow and habitat dependent, would result in significant effects on biomass of the fish components. Yet an instream flow assessment based on physical habitat for fishes would not capture these potential effects. Further, the model predicts complex responses to invertebrate declines (e.g., not every carnivore declined due to invertebrate declines), presumably due to changes in competitive pressures (Table I).

In other river systems the food web influence via competition or predation may play an equally important role with streamflow in the recovery of endangered fishes. Introduction of trout and other non-native fishes in the upper Colorado River basin may limit the recovery of endangered fishes regardless of the flows provided to meet the habitat needs of endangered fish (STANFORD, 1994).

\section{INDIVIDUAL-BASED MODELS}

Solution of the instream flow dilemma requires further estimation via simulation of the performance of target components. The most recent technical development in instream flow assessment is the use of individual-based models for stream fish. The model developed for smallmouth bass explicitly describes the daily processes of foraging, growth, survival, movement, and reproduction on an individual fish basis (JAGER et al., 1993). The current version of the model uses time series data for daily temperature and traditional PHABSIM descriptions of the spatial mosaic of hydraulic and channel characteristics of habitat. The traditional output of PHABSIM, weighted usable area, is replaced with a mechanistic population model. The individual-based modeling approach derives population attributes as emergent properties of the status of each of the individual fish. Individual fish can respond to the dynamic and heterogeneous stream habitat.

There are four reasons for concentrating on this alternative approach for instream flow assessment. Previous techniques for recommending instream flows have been difficult or impossible to test or refine. Therefore, improvements in instream flow assessment knowledge have been slow. Second, behavioral responses, such as re-nesting by male or female smallmouth bass or refuge-seeking behaviors, must be incorporated into instream flow assessments that address fluctuating flows. Third, the spatial and temporal variation in the importance of food or space as limiting factors can only be addressed by measuring consumptive demand and prey supply and replenishment, as well as the size-dependent space requirements. Finally, if habitat bottlenecks that limit population abundance are identified, this approach will be more useful for testing and devising mitigation strategies that recognize and take advantage of the unique individual attributes and capabilities of the fish. Despite its advantages, the individual-based modeling approach is still a single species approach with significant data requirements.

\section{MESO-SCALE ANALYSES}

Currently, data requirements for an individual-based approach are beyond the scope of understanding for practical instream flow assessment on some species. Yet, reliable advice must be provided to managers today. Rather than address the needs of species individually via IFIM or individual-based models, alternative methods are needed to serve as conceptual bridges between the two. One approach is a guild-level habitat analysis. VADAS (1994) developed habitat suitability criteria for seven guilds of stream fishes and found that habitat use at a guild level was more predictable than past species-level assessments. Predictions of habitat use were more predictable across study sites and years for the four rheophilic guilds than for the three limnophilic guilds. 
Tableau I : Biomasse annuelle moyenne (poids sec) de 13 compartiments d'un modèle de flux d'énergie pour la New River et prédiction de l'effet dû à une perte de $10 \%$ de la production d'insectes aquatiques (d'après ROELL, 1989).

Table I : Mean annual biomass (wet weight) of thirteen components of an energy flow model for the New River and predicted effects of a $10 \%$ loss of aquatic insect production (from ROELL, 1989).

Biomass

$\mathrm{g} \mathrm{m}^{-2}$
Percent change due to

$10 \%$ loss of aquatic

insect production
Aquatic Insects

Crayfish (age 1-2)

Hellgrammites (age 1-2)

Prey fishes

0.44

Smallmouth Bass

age 0

Rock Bass

Flathead catfish
0.57

0.60

1.06

age $2+$

age 0

age $2+$

age 0

0.09

age 1-3

0.27

0.18

$-15$

$-24$

$-24$

$-19$

0

age 4+ 
In order to adopt a more ecosystem-oriented approach for practical instream flow assessments, biologists should focus more attention on describing critical ecosystem functions and how they depend on flow-dependent habitat types. Most previous research has focused on structural elements of communities -- what are the species in each habitat ? However, a picture should now be emerging that permits us to describe the assemblages of many species that use similar habitats, mesohabitats, and microhabitats. In Figure 1 , available mesohabitats are depicted in two dimensions for simplicity although the original descriptions are multi-dimensional (LOBB and ORTH, 1991 ; AADLAND, 1993 ; RABENI and JACOBSON, 1993a, 1993b). These and other approaches may be used to simplify analyses for diverse communities and protect the diversity of aquatic habitats (GORE et al., 1992). The challenge for future research is to continue to define ecosystem processes that depend on these mesohabitats so we can begin to develop a matrix of ecosystem functions by mesohabitat. This information would complement our current species-habitat association data. This approach could be applied today as a simple and practical way to protect aquatic ecosystems and their biotic resources in a cost-effective manner.

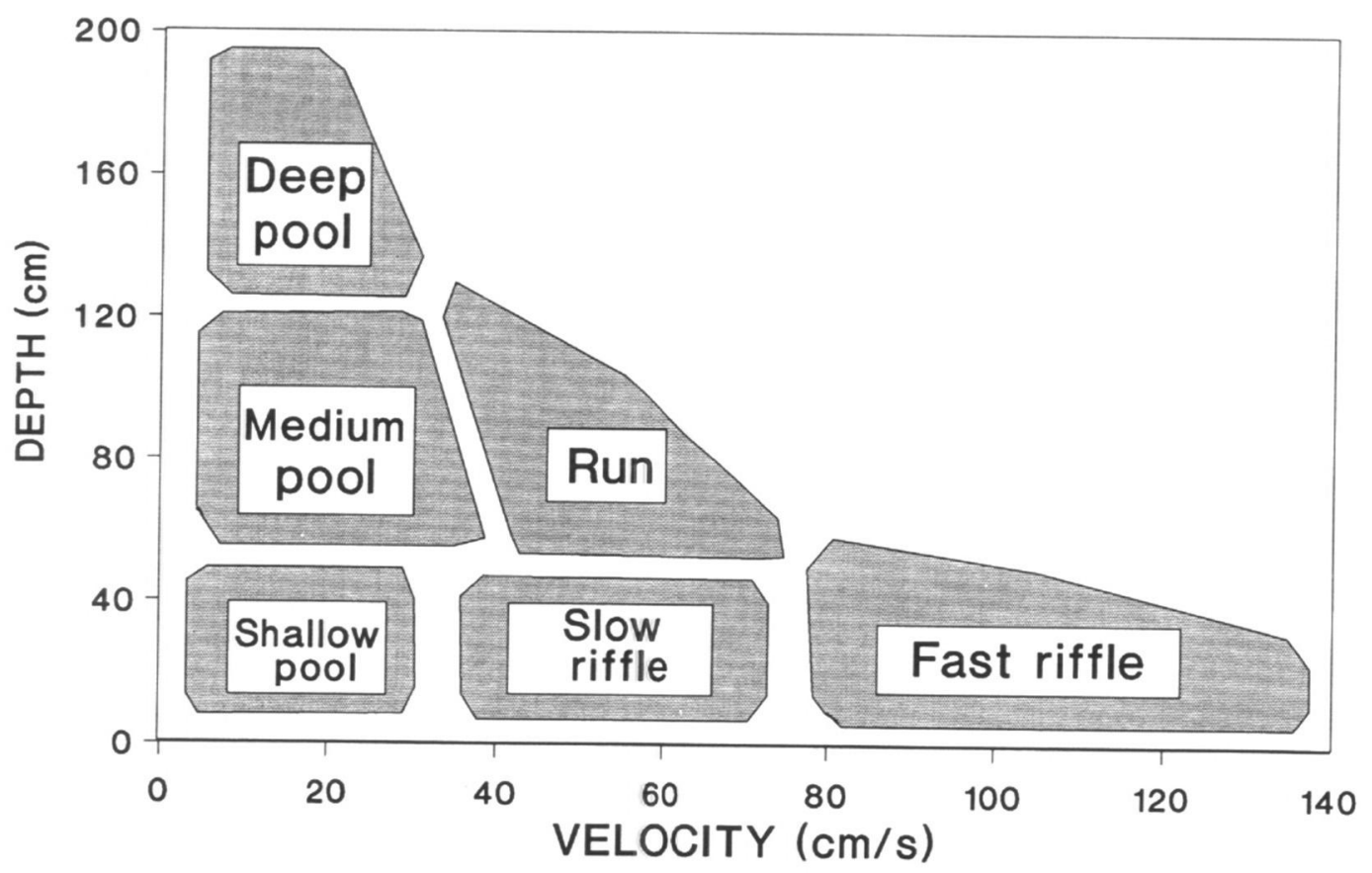

Figure 1 : Polygones décrivant les types communs de mésohabitats dans les ruisseaux (adapté de LOBB et ORTH, 1991; AADLAND, 1993 ; RABENI et JACOBSON, 1993b).

Figure 1 : Polygons describing common mesohabitat types in streams (adapted from LOBB and ORTH, 1991 ; AADLAND, 1993 ; RABENI and JACOBSON, 1993b).

\section{CONCLUSIONS}

Today, we possess better technical capabilities to protect critical stream habitats in the face of water resource development than we ever had in the past. The continued disagreement over technologies for instream flow assessments, such as the Instream Flow Incremental Methodology (IFIM), is not unlike controversies over application of other complex technologies (LAMB, 1989). Our debates should continue so that we improve the knowledge on which we base decisions about water allocation and flow releases. 
Future research and practical instream flow assessments should address the following issues:

1. A broader array of taxa should be considered in assessments and researchers must continue to explore the complex interrelationships among unrelated organisms.

2. Instream flow assessments should concentrate on the suspected sensitive species or guilds of organisms. Some patterns have emerged from past research on sensitivities to flow regulation.

3. Instream flow assessments can be simplified and, perhaps, yield more robust predictions if they focus on predicting the diversity and abundance of habitats. Research on the efficacy of meso-scale analyses can provide more guidance in this regard.

4. Research is needed to more clearly demonstrate the indirect effects of flow in altering food webs.

5. Habitat suitability criteria must be more rigorously tested and linked to some measures of individual fitness (e.g., feeding success, KWAK et al., 1992 ; HILL and GROSSMAN, 1993).

6. Individual-based models offer one avenue for exploring the potential indirect effects of flow alteration as well as the compensatory responses that may mitigate for flow alterations.

\section{ACKNOWLEDGEMENTS}

I thank M.B. BAIN, K.D. FAUSCH, K.S. HOCKETT, W.L. KNOTEK, E.J. PERT, and M.J. ROELL for reviewing earlier versions of this manuscript, and P. GAUDIN and $Y$. SOUCHON for the invitation to prepare and present this synthesis paper.

\section{REFERENCES}

AADLAND L.P., 1993. Stream habitat types : their fish assemblages and relationship to flow. N. Am. J. Fish Manage., 13, 790-806.

BAYLEY P.B., LI H.W., 1992. Riverine fishes. In Calow P., Petts G. E. (eds.), The rivers handbook. Hydrological and ecological principles, 251-281, Blackwell Scient. Publ., London.

BOVEE K.D., 1988. Use of the instream flow incremental methodology to evaluate influences of microhabitat variability on trout populations in four Colorado streams. Annu. Conf., West. Assoc. Fish and Wildl. Agencies, 6, 227-257.

BOVEE K.D., NEWCOMB T.J., COON T.G., 1994. Relations between habitat variability and population dynamics of bass in the Huron River, Michigan. National Biological Survey, U.S. Department of the Interior, Biological Report 21,63 p.

BOWLBY J.N., ROFF J.C., 1986. Trophic structure in southern Ontario streams. Ecology, 67, 1670-1679.

CAIRNS J., JR., 1986. The myth of the most sensitive species. BioScience, 36, 670-672.

CHAPMAN D.W., 1966. Food and space as regulators of salmonid populations in streams. Am. Nat., 100, 345-357.

CLOSS G.P., LAKE P.S., 1994. Spatial and temporal variation in the structure of an intermittent-stream food web. Ecol. Monogr., 64, 1-21.

EASTON R.S., ORTH D.J., 1992. Ontogenetic diet shifts of age-0 smallmouth bass (Micropterus dolomieu Lacepède) in the New River, West Virginia, USA. Ecol. Freshwat. Fish, 1, 86-98.

FARGO J.M., 1991. Evaluating relicense proposals at the Federal Energy Regulatory Commission. Federal Energy Regulatory Commission, Office of Hydropower Licensing, Paper No. DPR--2, 16 p. 
GEORGIAN T., THORP J.H., 1992. Effects of microhabitat selection on feeding rates of net-spinning caddisfly larvae. Ecology, 73, 229-240.

GORE J.A., 1989. Models for predicting benthic macroinvertebrate habitat suitability under regulated flows. In Gore J.A. and Petts G.E. (eds.), Alternatives in regulated river management, 254-265, CRC Press Inc., Boca Raton, Florida.

GORE J.A., LAYZER J.B., RUSSELL I.A., 1992. Non-traditional applications of instream flow techniques for conserving habitat for biota in the Sabie River of southern Africa. In Boon P.J., Calow P. and Petts G.E, (eds.), River Conservation and Management, 161-177, John Wiley \& Sons Ltd.

GRANT J.W.A., KRAMER D.L., 1990. Territory size as a predictor of the upper limit to population density of juvenile salmonids in streams. Can. J. Fish. Aquat. Sci., 47, 1724-1737.

GROSSMAN G.D., DOWD J.F., CRAWFORD M., 1990. Assemblage stability in stream fishes : a review. Environ. Manage., 14, 661-671.

HAUER F.R., BENKE A.C., 1991. Rapid growth of snag-dwelling chironomids in a blackwater river: the influence of temperature and discharge. J. N. Am. Benthol. Soc., 10, 54-164.

HILL J., GROSSMAN G.D., 1993. An energetic model of microhabitat use for rainbow trout and rosyside dace. Ecology, 74, 685-698.

HILL M.T., PLATTS W.S., BESCHTA R.L., 1991. Ecological and geomorphological concepts for instream and out-of-channel flow requirements. Rivers, 2, 198-210.

HUGHES R.M., NOSS R.F., 1992. Biological diversity and biological integrity : current concerns for lakes and streams. Fisheries, 17, 11-19.

IRVINE J.R., JOWETT I.G., SCOTT D., 1987. A test of the instream flow incremental methodology for underyearling rainbow trout, Salmo gairdneri, in experimental New Zealand streams. NZ J. Mar. Freshw. Res., 21, 35-40.

JAGER H I., DEANGELIS D.L., SALE M.J., VAN WINKLE W., SCHMOYER D.D., SABO M.J., ORTH D.J., LUKAS J.A., 1993. An individual-based model for smallmouth bass reproduction and young-of-year dynamics in streams. Rivers, 4, 91-113.

JENNINGS M.J., PHILIPP D.P., 1994. Biotic and abiotic factors affecting survival of early life intervals of a stream-dwelling sunfish. Environ. Biol. Fish., 39, 153-159.

JOWETT I.G., 1992. Models of the abundance of large brown trout in New Zealand rivers. N. Am. J. Fish. Manage., 12, 417-432.

JOWETT I.G., RICHARDSON J., BIGGS J.F., HICKEY C.W., QUINN J.M., 1991. Microhabitat preferences of benthic invertebrates and the development of generalised Deleatidium spp. habitat suitability curves, applied to four New Zealand streams. NZ J. Mar. Freshw. Res., 25, 187-199.

KWAK T.J., WILEY M.J., OSBORNE L.L., LARIMORE R.W., 1992. Application of diel feeding chronology to habitat suitability analysis of warmwater stream fishes. Can. J. Fish. Aquat. Sci., 49, 1417-1430.

LAMB B.L., 1989. Comprehensive technologies and decision-making : reflections on the Instream Flow Incremental Methodology. Fisheries, 14, 12-16.

LEONARD P.M., ORTH D.J., 1988. Use of habitat guilds of fishes to determine instream flow requirements. N. Am. J. Fish. Manage., 8, 399-409.

LOAR J.M. and ten coauthors, 1985. Application of habitat evaluation models in southern Appalachian trout streams. Oak Ridge National Laboratory, Environmental Science Division Publication 2383, $310 \mathrm{p}$.

LOBB M.D., III, ORTH D.J., 1991. Habitat use by an assemblage of fish in a large warmwater stream. Trans. Am. Fish. Soc., 120, 65-78. 
MCDOWALL R.M., 1993. Implications of diadromy for the structuring and modelling of riverine fish communities in New Zealand. NZ J. Mar. Freshwat. Res., 27, 453-453.

McELRAVY E.P., LAMBERTI G.A., RESH V.H., 1989. Year-to-year variation in the aquatic macroinvertebrate fauna of a northern California stream. J. N. Am. Benthol. Soc., 8, 51-63.

MENGE B.A., OLSON A.M., 1990. Role of scale and environmental factors in regulation of community structure. Trends Ecol. Evolution, 5, 2-57.

MEYER J.L., 1990. A blackwater perspective on riverine ecosystems. BioScience, 40, 643-651.

MORGAN R.P., II, JACOBSEN R.E., WEISBERG S.B., McDOWELL L.A., WILSON H.T., 1991. Effects of flow alteration on benthic macroinvertebrate communities below the Brighton Hydroelectric Dam. J. Freshw. Ecol., 6, 419-430.

MORIN A., PETERS R.H., 1988. Effect of microhabitat features, seston quality, and periphyton on abundance of overwintering black fly larvae in southern Quebec. Limnol. Oceanogr., 33, 431-446.

NEHRING R.B., ANDERSON R.M., 1993. Determination of population-limiting critical salmonid habitats in Colorado streams using IFIM/PHABSIM. Rivers, 4, 1-19.

NESTLER J.M., MILHOUS R.T., LAYZER J.B., 1989. Instream habitat modeling techniques. In Gore J.A., Petts G.E. (eds.), Alternatives in regulated river management, 295-315, CRC Press, Boca Raton, Florida.

NIELSEN L.A., ORTH D.J., 1988. The hellgrammite-crayfish bait fishery of the New River and its tributaries, West Virginia. N. Am. J. Fish. Manage., 8, 317-324.

NILSSON C., EKBLAD A., GARDFJELL M., CARLBERG B., 1991. Long-term effects of river regulation on river margin vegetation. J. Appl. Ecol., 28, 963-987.

ORTH D.J., JONES R.N., MAUGHAN. O.E., 1982. Species composition and relative abundance of benthic macroinvertebrates in Glover Creek, southeast Oklahoma. Proc. Okla. Acad. Sci., 62, 18-21.

ORTH D.J., MAUGHAN O.E., 1984. Community structure and seasonal changes in standing stocks of fish in a warm-water stream. Am. Midl. Nat., 112, 369-378.

OSBORNE L.L., HERRICKS E.E., 1987. Microhabitat characteristics of Hydropsyche (Trichoptera : Hydropsychidae) and the importance of body size. J. N. Am. Benthol. Soc., 6, 115-124.

PETTS G.E., 1984. Impounded rivers : perspectives for ecological management. John Wiley \& Sons Inc. $326 \mathrm{p}$.

POWER M.C., 1990. Effects of fish in river food webs. Science, 250, 411-415.

POWER M.C., 1992. Top-down and bottom-up forces in food webs : do plants have primacy? Ecology, 73, 733-746.

PUSEY B.J., ARTHINGTON A.H., 1991. The utility and applicability of the in-stream flow incremental methodology (IFIM) for Australian lotic environments. Verh. Internat. Verein. Limnol., 24, 2559.

RABENI C.F., JACOBSON R.B., 1993a. Geomorphic and hydraulic influences on the abundance and distribution of stream centrarchids in Ozark USA streams. Pol. Arch. Hydrobiol., 40, 87-99.

RABENI C.F., JACOBSON R.B., 1993b. The importance of fluvial hydraulics to fish-habitat restoration in low-gradient alluvial streams. Freshwat. Biol., 29, 211-220.

REICE S.R., WISSMAR R.C., NAIMAN R.J., 1990. Disturbance regimes, resilience, and recovery of animal communities and habitats in lotic ecosystems. Environ. Manage., 14, 647-659.

RESH V.H., BROWN A.V., COVICH A.P., GURTZ M.E., LI H.W., MINSHALL G.W., REICE S.R., SHELDON A.L., WALLACE J.B., WISSMAR R.C., 1988. The role of disturbance theory in stream ecology. J. N. Am. Benthol. Soc., 7, 433-455. 
ROELL M.J., 1989. The roles of predation, competition, and exploitation in the community dynamics of the New River in West Virginia. Doctoral diss., Virginia Polytechnic Inst. \& State Univ., Blacksburg. 248 p.

ROELL M.J., ORTH D.J., 1993. Trophic basis of production of stream-dwelling smallmouth bass, rock bass, and flathead catfish in relation to invertebrate bait harvest. Trans. Am. Fish. Soc., 122, 46-62.

ROELL M.J., ORTH D.J., 1994. The roles of predation, competition, and exploitation in the trophic dynamics of a warmwater stream : a model synthesis, analysis, and application. Hydrobiologia, 291, 157-178.

ROSGEN D. L., 1994. A classification of natural rivers. Catena, 22, 169-199.

SCHLOSSER I.J., 1991. Stream fish ecology : a landscape perspective. BioScience, 41, 704-712.

SCHLOSSER I.J., EBEL K.K., 1989. Effects of flow regime and cyprinid predation on a headwater stream. Ecol. Monogr., 59, 41-57.

SCOTT D., SHIRVELL C.S., 1987. A critique of the instream flow incremental methodology and observations on flow determinations in New Zealand. In Craig J.F., Kemper J.B. (eds.), Regulated streams, 27-43, Plenum Publishing Corp.

STANFORD J.A., 1994. Instream flows to assist the recovery of endangered fishes of the upper Colorado River basin. U.S. Dept. Interior, National Biol. Surv., Biol. Rep. 24. 47 p.

STRANGE E.M., MOYLE P.B., FOIN T.C., 1992. Interactions between stochastic and deterministic processes in stream fish community assembly. Environ. Biol. Fish., 36, $1-15$.

STROMBERG J.C., PATTEN D.T., 1991. Instream flow requirements for cottonwoods at Bishop Creek, Inyo County, California. Rivers, 2, 1-11.

TITUS R.G. 1990. Territorial behavior and its role in population regulation of young brown trout (Salmo trutta) : new perspectives. Ann. Zool. Fennici, 27, 119-130.

VADAS R.L., JR., 1994. Habitat tools for assessing instream-flow needs for fishes in the upper Roanoke River, Virginia. Doctoral diss., Virginia Polytechnic Inst. \& State Univ., Blacksburg. $346 \mathrm{p}$.

WARREN C.E., WALES J.H., DAVIS G.E., DOUDOROFF P., 1964. Trout production in an experimental stream enriched with sucrose. J. Wildl. Manage., 28, 617-660.

WATERS T.F., 1982. Annual production by a stream brook charr population and by its principal invertebrate food. Environ. Biol. Fish., 7, 165-170.

WEISBERG S.B., BURTON W.H., 1993. Enhancement of fish feeding and growth following an increase in minimum flow below the Conowingo Dam. N. Am. J. Fish. Manage., 13, 103-109.

WEISBERG S.B., JANICKI A.J., GERRITSEN J., WILSON H.T., 1990. Enhancement of benthic macroinvertebrates by minimum flow from a hydroelectric dam. Regulated Rivers: Res. \& Manage., 5, 265-277.

WETMORE S.H., MACKAY R.J., NEWBURY R.W., 1990. Characterization of the hydraulic habitat of Brachycentrus occidentalis, a filter-feeding caddisfly. J. N. Am. Benthol. Soc., 9, 157-169.

WILEY M.J., OSBORNE L.L., LARIMORE R.W., KWAK T.J., 1987. Augmenting concepts and techniques for examining critical flow requirements of Illinois stream fisheries. Illinois Natural History Survey, Aquatic Biology Section, Technical Report 87/5, Urbana, Illinois. $260 \mathrm{p}$. 